\title{
Örsi Julianna
}

\section{Helyreállítható-e az organikus társadalmi intézmények presztízse? \\ Középiskolás diákok véleménye a házasságról és a családról Jász-Nagykun-Szolnok megyében}

Örsi, Julianna: Could be Restored the Prestige of the Organic Socilal Institution?
High school students' opininons about marriage and family in Jász-Nagykun-Szolnok County

The research examines the family and the marriage from young generation's perspective. On one hand, opinions of today's young people before mate choice reflect the status of nowadays family, habits; on the other hand they predict the behavior of the next generation in relation with family founding.

Keywords: social research, beging of independent living, career choices, forms of coexistence, generations

\section{ÖSSZEFOGLALó}

A kutatás a család, a házasság intézményét vizsgálja a fiatal nemzedék szemszögéből. A mai, párválasztás előtt álló fiatalok véleménye egyrészt tükrözi a jelen családi állapotokat, szokásokat, másrészt előrevetíti a következő generáció a családalapítással kapcsolatos magatartását.

Kulcsszavak: társadalomkutatás, önálló életkezdés, pályaválasztás, együttélési formák, generációk

\section{A KUTATÁS TÁRSADALMI SZÜKSÉGESSÉGE}

Napjainkban a gazdasági nehézségek miatt mind az egyének, mind a társadalom újabb és újabb megszorításokra kényszerül. Mindenki ott spórol, ahol tud. A lemondások, legtöbbször a kulturális javak területén kezdődnek. Nincs ez másképp a tudományos kutatás területén is. Vannak, akik úgy vélik, elodázhatók a társadalomkutatások (ezen belül a bölcsészettudományaik). Ennek ellentmond az a tény, hogy gazdasági fellendülés nincs stabil társadalmi intézmények nélkül. A 20. századi rendszervál- tások megváltoztatták a társadalom belső szerkezetét. Az embereket körülvevő világ bizonytalanságot szült, amely hatott a gondolkodásra, viselkedésre egyaránt. Az országban kialakult az erkölcsi válság is. Ez pedig nem kerülte el a társadalom legkisebb organikus egységét, a családot sem. Ebből a helyzetből ki kell vezetni az ország népét, mert súlyos következményei vannak és lesznek. Ezek közül csak a kedvezőtlen demográfiai folyamatokat említem. Erősen fogy a magyar népesség. (3-5 kép: családi állapot változása 1869-2011)

Az ország vezetői, a döntéshozók felelőssége, hogy az állam milyen intézkedéseket hoz a válságból való kiláboláshoz. A társadalomkutatók is hozzá tudnak járulni a társadalom fejlődésének helyes irányba való tereléséhez. Mivel? a.) A reális helyzetkép felrajzolásával, b.) Pozitív példák felmutatásával.

Mondhatnánk, hogy mindezt megteszik az állam által finanszírozott tudományos intézetek. Tény, hogy a Magyar Tudományos Akadémia egész intézményhálózatot működtet és a minisztériumoknak is megvannak a témával foglalkozó háttérintézményei. Az ott dolgozók 
széles apparátussal, kellő technikai felszereltséggel valóban pontos képet adnak a makrotársadalom működéséről és megfogalmazzák a javaslataikat is. Viszonylag kevesen vannak azonban azok, akik a mikro-társadalom kutatásában mélyülnek el. Különösen kevesen, akik a vidék társadalmának működését mélyfuráson keresztül, belülről ismerik. Ezen kevesek közzé tartozik a Jász-Nagykun-Szolnok Megyei Tudományos Egyesület egy tucat kutatója, akik fáradhatatlan munkával újabb és újabb kutatásba kezdenek, újabb és újabb konferenciákon adnak számot kutatási eredményeikről, jelentetik meg könyveiket és hívják fel a figyelmet a jászkun, tágabb értelemben a megye, a vidék problémáira. (PI. a Termelés és fogyasztás a Jászkunságban című konferencia, monografikus kutatások stb.)

\section{A KUTATÁS ELŐZMÉNYEI}

Én magam az 1970-es évek közepétől vizsgálom, figyelem és élem a vidéki életet. Az eddigi írásaim elsősorban a nagykun települések közösségeiről szóltak, de az ország, sőt a Kárpát-medencében is végeztem hasonló vizsgálatokat. Érdeklődésem kiterjedt a szakirodalom (néprajz, szociológia, demográfia, történelem) folyamatos nyomon követésére is. Mindezek megalapozták, bátorságot adtak ahhoz ahhoz, hogy a nagykunsági család jelenképét megvizsgáljam. Partnerre leltem Herbály Katalinban, a Szolnoki Főiskola docensében. Segítséget adtak az intézményben dolgozó demonstrátorok valamint a kiválasztott célcsoportok intézményvezetői és állami- iiletve egyházi fenntartói.

\section{JELEN KUTATÁs CÉLJA, TÁRGYA}

Kutatásunk a család, a házasság intézményét vizsgálja különös tekintettel a fiatal nemzedék szemszögéből. A mai, párválasztás előtt álló fiatalok véleménye egyrészt tükrözi a jelen családi állapotokat, szokásokat, másrészt előrevetíti a következő generáció a családalapítással kapcsolatos magatartását. Kutatásunk eredményeit össze tudjuk mérni az 1970-es évektől évtizedenként megismétlődő nagykunsági vizsgálatokkal. Így a folyamatok pontosan nyomon követhetők. Jelen írásunk a most folyó kutatás első prezentációja. Részletesebb elemzést később tesszük közre.

\section{A KUTATÁS IDŐBELI ÉS FÖLDRAJZI MEGHATÁROZÁSA}

Jelen felmérésünket 2013 májusában végeztük Jász-Nagykun-Szolnok megye néhány településén. A nagykunsági városokat (Karcag, Kisújszállás, Kunhegyes és Túrkeve) jelöltük ki kutatópontnak. Olyan 8-20 ezer lakosú kisvárosok ezek, amelyek nagy múlttal, különállási tudattal rendelkeznek, azonos történelmi-néprajzi csoportba tartoznak. Valamennyi településen müködik középiskola, amelybe a helybelieken kívül a szomszédos falvak diákjai is tanulnak. Vonzáskörzetük főleg a Nagykunságra és a KözépTiszamentére terjed ki. Jelenleg a karcagi és a kisújszállási középiskola református egyházi, a kunhegyesi és a túrkevei állami fenntartású. A gimnázium mellett szakközépiskolai oktatás is folyik a falaik között. A Karcagi Nagykun Gimnáziumba az egészségügyi szakképzés elsősorban lányokat vonz, a túrkevei középiskolában az autószerelői irányultság miatt főleg fiúk tanulnak. A vizsgálatba - ellenpontként - bevontuk a jóval nagyobb lélekszámú megyeszékhely (Szolnok) egyik középiskoláját, amely a római katolikus egyház fenntartásában múködik.

A térség nemcsak a hétköznapi szóhasználatban minősül vidéknek, hanem az OECD besorolás alapján is. A vidék, vidékiség értelmezése azért is fontos, hiszen a vidéket jellemző családi házas településszerkezet, ahol a házkörüli teendők, a háztáji gazdálkodás a legtöbb esetben jelen van. Adott tehát az a minta, amit a fiatalok szüleiktől, nagyszüleiktől hallhatnak, láthatnak, az együttélés gazdasági és társadalmi vonatkozásait illetően.

\section{A KUTATÁS ALANYAI}

Már a fentiekből is látható, hogy középiskolás fiatalokat kérdeztünk meg. Mindannyian 3. (9.) 
évfolyam 16-17 éves tanulói, 52 \%-uk férfi, 48 \%-uk nő. A felmérésben résztvevő tanulók száma összesen 159 fö, mely a következőképpen oszlik meg:

Karcagi Nagykun Református Gimnázium, Egészségügyi

Szakközépiskola és Kollégium (Karcag)

Móricz Zsigmond Református

Gimnázium, Szakközépiskola

és Kollégium (Kisújszállás)

Móricz Zsigmond Református Gimnázium, Szakközépiskola és Kollégium (Kisújszállás)

Nagy László Gimnázium (Kunhegyes)

Tiszaparti Római Katolikus Általános 23 fó Iskola és Gimnázium (Szolnok)

Ványai Ambrus Gimnázium és Szakközépiskola (Túrkeve)

Összesen: a családtagok egymáshoz való viszonyát, a férj, a feleség szerepét. A női egyenjogúság kérdése elsősorban a női foglalkoztatás szempontjából került vizsgálat alá. A családi munkamegosztást és a gyermek munkára nevelését ugyancsak kutattuk. A foglalkozás-választás attitűdjeire is kíváncsiak voltunk. Vizsgálat alá vettük a generációk közötti kapcsolatot, a magatartás és gondolkodás közötti véleménykülönbséget. Végezetül adatokat kaptunk a fiatalok mobilitásra való hajlandóságára is.

\section{A KUTATÁs EREDMÉNYE}

A feltett kérdéseket 13 csoportba osztva értékeltük. Ezek a következők: együttélési formák, a házasságkötés melletti érvek, a párválasztás szempontjai és az ideális házastárs, az önálló élet kezdésének feltételei, ismerkedési lehetőségek, házasságkötés időpontja, életkor, gyermekvállalási kedv és családi modell, nők foglalkoztatása, munkamegosztás a családban, pályaválasztás, foglalkozás, családi gazdálkodás és fogyasztá, generációk kapcsolata, kötődés a településhez. A felmérés eredményéből itt most csak néhányat emelünk ki.

\section{1. ábra:}

\section{A KUTATÁSI TÉMA RÉSZLETEZÉSE}

Az önálló életkezdés feltételei Az önálló életkezdés feltételei

Kérdőivünk 50 kérdést tartalmaz a szociodemográfiai adatokon kívül. A kérdések egyik része az együttélés formáira vonatkozik, a házasságról alkotott véleményeket gyűjti össze. Az ismerkedési lehetőségekre és a párválasztás szempontjaira is rákérdeztünk. A kérdések másik csoportja a család működését állítja középpontba. Vizsgálja

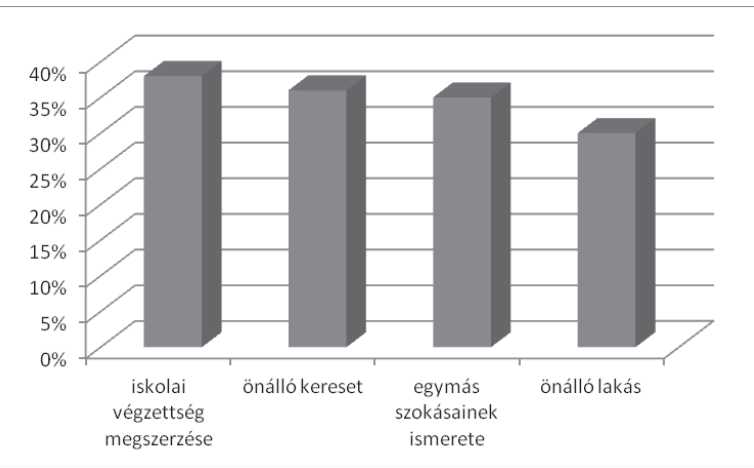


A középiskolás fiatalok az önálló élet megkezdése előtt legfontosabbnak tartják tanulmányaik befejezését, a tervezett iskolai végzettség megszerzését. (38\%) Ez biztosítja az önálló keresethez jutást. (36\%) Az önálló élet kezdéséhez fontosnak tartják, hogy egymás szokásait ismerjék. (35\%) Ugyancsak kiemelt helyen szerepel az önálló lakás biztosítása is. (30 \%)

A fiúk - számításaik szerint - 25-30 éves korukban kezdenek önálló életet. (65\%). Egyötödük azonban valószínűleg már a középiskola elvégzése után - 20-24 évesen - elszánja magát erre a döntő lépésre. (23 \%) A leányok korábban szeretnék kezdeni az önálló életet (0-24 évesen $41 \%$ ). A többi is célba akar érni a tanulmányai befejezése után. (25-30 évesen 51 \%) A kései kezdés magyarázata leggyakrabban mindkét nemnél a tanulmányok befejezése, az önálló egzisztencia megteremtése.

\section{Pályaválasztás, foglalkozás}

A 3. éves középiskolásokat megosztja a pályaválasztási szempontok rangsora. A legtöbben a jó kereseti lehetőséget helyezik előtérbe. (40\%) A munkalehetőség felmérése és a családi tradíció megközelítőleg egyenlően esik latba. (21 \% illetve $20 \%$ )

A fiatalok közel fele vállalkozóként képzeli el az életét (48\%), egyharmaduk alkalmazottként kíván elhelyezkedni. (35\%) A közalkalmazotti, köztisztviselői munkakörök népszerűsége alacsony. (5-10\%)

A foglalkozási csoportot illetően a legnépszerübb az értelmiségi pálya. (37 \%) A megkérdezettek alig egyötöde szeretne szakmunkás lenni (18 \%), ennél csak alig kevesebben „irodisták”, azaz adminisztratív munkakörben kívánnak dolgozni. (16\%) Jelentős azoknak az arányuk, akiknek nincs elképzelésük a jövőjükről. (29\%)

Itt fontosnak tartjuk a családi attitűdöt. A szocio-demográfiai adatokból kiderül, hogy megkérdezettek több mint felének szülei is középfokú végzettségűek (apa: 65 \%, anya: 57 \%).
Ezek között azonban az a jellemző, hogy a családfőnek szakmunkás végzettsége van. Ugyanakkor figyelemre méltó az is, hogy a felsőfokú végzettség sem ritka. A nőknél gyakoribb, mint a férfiaknál. Mindent összevetve a szülők képzettek (közép- és felsőfokú végzettséggel, szakmával rendelkeznek 88-89 \%-ban), amely bizonyára inspirálólag hat a gyermekekre is.

\section{A nők foglalkoztatása}

A középiskolások szerint a férjek nagy többsége helyesli, hogy a felesége munkahelyen dolgozik. (84 \%) Ugyanakkor a család szempontjából egyértelműen hátrányosnak ítélik meg, ha a nő dolgozik. (72 \%) A férjek többsége azt sem helyeseli, ha a feleség túlórázik. (81 \%) A nők sokirányú igénybevételének hátrányos következményei vannak. (82 \%) Az egyenlő munkáért egyenlő bér elvének érvényesülését csak részben tapasztalják. Valamivel többen mondják azt, hogy a nők megbecsülése időnként hátrányt szenved. (59\%)

Munkahelyi vezetőként többségük elsősorban a nők fizikai igénybevételén/terhelésén könnyítene, de felvetődik a túlóra megszüntetése, a részmunkaidőben történő foglalkoztatás, illetve a magasabb bérezés igénye is. Többen jelezték azonban azt is, hogy az egyenjogúság alapján nincs szükség semmiféle megkülönböztetésre a nemek alkalmazását illetően.

\section{Együttélési formák}

A megkérdezett fiatalok a legelfogadottabb együttélési formának a házasságot tartják. (77 \%) A házasságon kívüli együttélés elfogadottsága azonban közel áll ehhez az értékhez. (68,36 \%) A megkérdezettek közel egyharmada az egyedül élést is elfogadja alternatívaként. (32,02 \%) Ugyanakkor a fiatalok 3/4-ed részének egyéni tervében szerepel a házasságkötés. (75 \%) Egynegyedük a házasságon kívüli együttélést tervezi. (25\%) Szingliként senki sem szeretne élni. (0\%) A családi minta jelentősen 
befolyásolja a fiatalok véleményalkotását. 63 \%-uk rokonságában ugyanis van házasságon kívül együttélő pár. A nagykunsági fiatalok tehát alternatívaként már elfogadják a házasságon kívüli együttélést is, de saját életükben még mindig ragaszkodnak a házasságkötéshez.

\section{4. ábra: Együttélési formák}

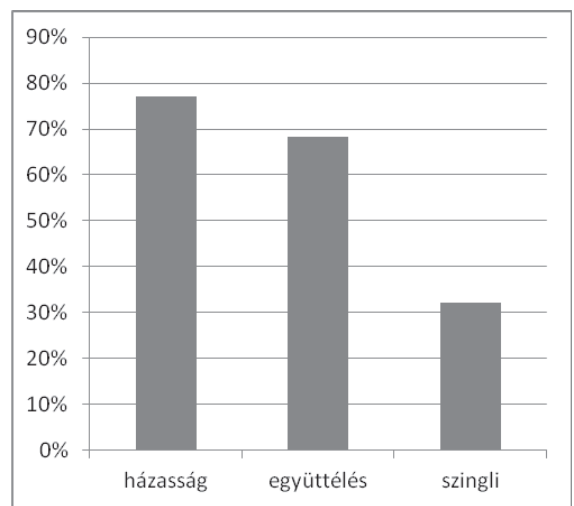

\section{A házasságkötés melletti érvek:}

A házasságkötés szükségét a leginkább a következőkben látják: a.) a házasság közös teherviselést jelent (73\%); b.) szeretnék családot alapítani (68\%); c.) a házasság szorosabb/erősebb köteléket jelent (64\%); d.) a házasság érzelmi és egyéb kötődést is jelent; mindenkinek kell egy boldog család; meghitt családi körben szeretnék élni (58 \%); e.) akit szeretek azzal szeretném összekötni az életemet; lesz mindig, akihez forduljak, akivel megosszam az életemet (57\%); f.) a házasságban lehet a társra támaszkodni (56\%); g.) nem szeretnék egyedül élni (52\%); h.) megtaláltam a partnert, akivel szeretném leélni az életemet. (51 \%) A szempontok között jelentősebbek még a következők: a házastársak kiegészítik egymást: „párosan szép az élet"; lesz mindig, akihez forduljak, akivel megosszam az örömöt, fontos a normális partneri kapcsolat, szeretnék egyszer menyasszonyi ruhában lenni. (40-50\%)
Saját életében tervezi a házasságkötést 84 \%, ami pozitiv. Sőt, 77 \% lakodalmat is szeretne rendezni, ami azt jelenti, hogy fontosnak tartja, hogy élete ezen eseményét a közösség (család, rokonság, barátok) is megünnepelje.

Sikertelen házasság, válás után fele-fele arányban kötnének újabb házasságot.

\section{A párválasztás szempontjai:}

A párválasztási szempontok között az alább sorrendet állították fel a fiatalok: 1.) szerelem, 2.) szimpátia, egészség, 3.) iskolai végzettség, 4.) foglalkozás, 5.) vagyon, 6.) a család hírneve, 7.) vallásosság, 8.) egyéb.

\section{Gyermekvállalási kedv és családi modell}

A fiatalok közel háromnegyede két gyermeket szeretne. (73 \%) Közel annyian terveznek több gyereket (14\%), mint amennyien egyet. (13\%) Elenyésző azoknak a száma, akik nem terveznek gyermeket.

Ezek a számok azért is fontosak számunkra, mert a szülői mintaadás hatékonyságát is le tudjuk mérni. A megkérdezettek $40 \%$-a él két gyermekes családban, $23 \%$-a háromgyermekes családban és $21 \%$-a kimondottan nagy (4-9 gyermekes) családban. Nincs testvére 16 \%-nak. A nagykunsági fiatalok tehát követik terveikben a családjuk modelljét, bár számszerűleg kevesebb lesz közöttük a nagycsaládos szülő.

\section{Generációk kapcsolata}

Felmérésünk is igazolja, hogy a családok döntő hányadára a két generáció (szülő, gyerek) együttélése jellemző. A megkérdezettek 90,51 \%-a nem él együtt a nagyszüleivel. Nem is tartanák helyesnek a háromgenerációs háztartásokat $(87,34 \%)$. Olyan minimális esetben fordul elő, hogy a nagyszülővel közös háztartást vezetnek, hogy kijelenthetjük, ezekben az esetekben is átmeneti állapotról van szó (amikor már az idős családtag gondozásra szorul). 
A nagyszülők segítik a kiscsaládot. A segités elsősorban anyagi segítséget jelent. (41,14 \%) A segítés másik módja a kisgyermekes családoknál gyakori. A dolgozó anya helyett a nagyszülők vigyáznak a beteg gyerekre. (42,41 \%) Ezt családi szinten pénzben nem mérik, természetbeni segítségnek tekintik. Az idősek egyéb munkájukra kevésbé tartanak igényt. (6,96 \%) A kiscsalád elsősorban betegség esetén segíti a nagyszülőket. (39,87 \%) Szükség esetén az idős ember számíthat egyéb módon is a segítségre (étkezés biztosítása, pénz, 18-15\%).

A három generáció között még megvan a hagyományos, jó kapcsolat. Szükség esetén a segítségadás kölcsönös. Ezen túl is rendszeres a kapcsolattartás. A megkérdezettek fele hetente látogatja a nagyszüleit. (51 \%) Egyharmaduk napi kapcsolatban vannak az idősebb generációval. (30 \%) Ezt, természetesnek veszik, hiszen ugyanazon településen élnek. Ha még a havi látogatást - ami a más településen éléssel is magyarázható - is elfogadhatónak tartjuk (14 $\%)$, akkor megállapíthatjuk, hogy a vizsgált településeken még eleven a generációk közötti kapcsolattartás, a szolidaritás.

\section{Kötődés a településhez}

A jelenlegi középiskolások többsége más településen képzeli el a jövőjét. (87 \%) Ez bizony a vidéki kisvárosok szempontjából szomorú előrejelzés. A fiatalok úgy látják, hogy lakóhely- ükön nem biztosított a családalapítás alapja, a megélhetés, a biztos jövő. Az elvágyódás mögött nem a fiatalos romantika, hanem a valóságos tényekkel való reális számvetés van. Abból a szempontból is negatív ez a jelenség, ha azt is figyelembe vesszük, hogy a megkérdezettek vállalkozóként, szakemberként, értelmiségiként vágyódnak el a vidékról. Ez negatív kiválasztódást eredményez. Ugyanakkor a vidékről elköltöző falvak, kisvárosok elöregedését, népességcsökkenését is előrevetíti.

\section{Összegzés}

Kutatásunk első eredményeit összegezve megállapíthatjuk, hogy a Nagykunságon és környékén a fiatal nemzedék neveltetésénél fogva még éli a hagyományos vidéki kiscsalád életét, megvan a kapcsolat a generációk között, de már elfogadja az újabb, városi szemlélet által közvetített értékeket is. A pozitív folyamatok mellett az egyre több negatív jelenség fellazítja a családi közösséget, a helyi társadalmat. Végső soron a vidék fejlődését akadályozza. Az ország és a helyi társadalom vezetőinek, a vidékfejlesztésre annak gazdasági és társadalmi feltételeinek javítására nagyobb figyelmet kell fordítaniuk. Az ország fejlődésének fontos területe a vidéki fiatal, a vidéki ember, vidéki család életfeltételeinek javítása. 